

\title{
Peran Kepuasan dalam Memediasi Pengaruh Persepsi Nilai Pasca Pembelian Terhadap Minat Beli Ulang Pengguna Vending Machine Blue Mart
}

\author{
(The Role of Satisfaction in Mediating the Effect of Post Purchase \\ Value Perceptions on Purchase Intention of Blue Mart Vending \\ Machine Users)
}

\section{Bayu Umara1; Dudy Suryadi²; Gita Yulianti³; Septi Isnaeni4; Yulia Tumini $^{5}$}

\begin{abstract}
ABSTRAK
Setiap perusahaan berupaya untuk dapat menjaring konsumen yang diawali dengan menumbuhkan minat beli. Berbagai cara dilakukan, salah satunya yang dilakukan oleh Blue Mart, yaitu dengan menyediakan mesin penjual otomatis atau vending maching. Konsumen diharapkan akan memiliki persepsi nilai yang baik berdasar pengalaman atau informasi pihak lain yang pernah melakukan pembelian melalui vending maching. Penelitian ini bertujuan untuk menganalisis pengaruh persepsi nilai terhadap minat beli ulang secara langsung dan tidak langsung melalui kepuasn konsumen. Penelitian dilakukan dengan menyebarkan kuesioner melalui google form selama bulan November 2020 kepada konsumen Vending Machine Blue Mart. Kuesioner yang terkumpul dan memenuhi kriteria sebagai data penelitian sebanyak 186. Structural Equation Modelling menggunakan AMOS Versi 23 digunakan untuk menganalisis data. Temuan penelitian menunjukkan bahwa persepsi nilai pasca pembelian mempengaruhi minat beli ulang konsumen Blue Mart menggunakan vending machine secara langsung atau tidak langsung yang dimediasi oleh kepuasan konsumen.
\end{abstract}

Kata Kunci: Persepsi Nilai, Minat Beli Ulang, Kepuasan

Kode JEL:

\footnotetext{
1 Prodi Magister Manajemen Universitas Pelita Bangsa; bayuumara010@gmail.com

2 Prodi Magister Manajemen Universitas Pelita Bangsa; Shc.dudi@gmail.com

3 Prodi Magister Manajemen Universitas Pelita Bangsa; Yulia khanzaaep@gmail.com

4 Prodi Magister Manajemen Universitas Pelita Bangsa; Isnasepti.is@gmail.com

${ }^{5}$ Prodi Magister Manajemen Universitas Pelita Bangsa; Gita.vandawa@yahoo.com
} 


\begin{abstract}
Every company strives to be able to attract consumers, starting with growing interest in buying. There are various ways to do it, one of which is done by Blue Mart, namely by providing a vending machine. Consumers are expected to have a good perception of value based on the experience or information of other parties who have made purchases through vending maching. This study aims to analyze the effect of perceived value on repurchase interest directly and indirectly through consumer satisfaction. The research was conducted by distributing questionnaires via google form during November 2020 to Vending Machine Blue Mart consumers. The questionnaires that were collected and met the criteria as research data were 186. Structural Equation Modeling using AMOS Version 23 was used to analyze the data. The research findings show that the perception of post-purchase value affects consumer repurchase interest in Blue Mart using vending machines directly or indirectly mediated by consumer satisfaction.
\end{abstract}

Keywords : Perceived Value, Repurchase Interest, Satisfaction Kode JEL:

\title{
1. Pendahuluan
}

Konsumen saat ini mengharapkan model transaksi yang mudah, cepat, menaikkan gengsi, aman, nyaman dan berkualitas sehingga harga seringkali bukan hal yang menjadi perhatian. Hal ini disebabkan oleh perubahan minat masyarakat. Salah satu yang merespon dengan cepat pergeseran pola pembelian konsumen tersebut adalah platfom berbasis digital Blue Mart. Blue Mart berupaya untuk menarik minat konsumen dengan menerapkan pola pembelian baru yaitu dengan menggunakan mesin belanja otomatis (Vending Machine).

Terobosan yang dilakukan Blue Mart merupakan salah satu upaya untuk mendapatkan pangsa pasar. Strategi yang dilakukan adalah dengan memperbanyak Vending Maching. Blue Mart menempatkan gerai yang tersebar kota-kota besar di Indonesia. Jakarta, Bandung, Surabaya, Medan, Semarang, dan Joga adalah diantaranya. Penempatan gerai di lokasi strategis, tempat umum, kampus dan lain-lain adalah upaya untuk menarik minat konsumen. Minat beli konsumen merupakan tahap awal untuk mendorong konsumen melakukan pembelian yang sesungguhnya. Minat beli ulang menjadi semakin penting karena akan mendorong loyalitas (Kurniawan, santoso, \& Dwiyanto, 2007). Minat beli dapat dipahami sebagai tingkat dimana konsumen punya niatan membeli kembali suatu produk yang pernah dibelinya. Minat konsumen memiliki tipe yang beragam seperti transaksional, referensional, preferensional dan ekspoorasi (Ferdinand, 2002a).

Banyak faktor yang dapat mempengaruhi minat konsumen. Faktor tersebut adalah kepercayaan (Adji \& Semuel, 2014; Mulyanto, Rasipan, \& Andriani, 2018), kualitas layanan dan brand image (Pradini, 2012) serta bauran pemasaran (Putra, Lapian, \& Lumanauw, 2014). Bauran promosi dan kesadaran merek merupakan 
faktor lain yang dapat mempengaruhi minat beli ulang (Repi, Lumanaw, \& Wenas, 2020).

Persepsi nilai menjadi salah satu faktor yang banyak diteliti (Mariah \& Nurbaeti, 2019; Repi et al., 2020; Wiryantari \& Sukawati, 2016). Persepsi nilai dapat muncul dari informasi pihak lain atau pengalaman yang dirasakan konsumen. Informasi yang ditangkap konsumen dari pengalaman dirinya dan orang lain mempengaruhi persepsi pada produk atau jasa yang berniat dibelinya. Persepsi nilai tersebut muncul dengan memperbandingkan manfaat yang diterima dengan pengorbanan yang dilakukan.

Penelitian sebelumnya tentang persepsi nilai dan minat beli memiliki model beragam. Salah satunya menempatkan kepercayaan sebagai mediasi pengaruh persepsi nilai tehadap minat beli (Wulandari \& Ekawati, 2015). Penelitian lain menempatkan kepuasan sebagai mediator pengaruh bauran pemasaran terhadap minat beli (Sudibyo, Margo, \& Andreani, 2015). Peneliti berikutnya tentang pengaruh ekspektasi pelanggan dan aplikasi bauran pemasaran dan ekspektasi pelanggan terhadap minat beli (Semuel, 2006).

Penelitian ini berupaya mengisi kesenjangan penelitian sebelumnya dengan mengkombinasikan dan menambahkan kepuasan sebagai variabel yang memediasi pengaruh persepsi nilai terhadap minat beli ulang. Pendekatan penelitian menggunakan teori ekspektasi konfirmasi (Oliver, 1981) dimana harapan dan persepsi mengarah pada kepuasan dan mempengaruhi niat pembelian (Thong, Hong, \& Tam, 2002). Penggunaan mesin otomatis pada Blue Mart yang mudah, praktis, cepat dan memberikan kesan yang modern membuat konsumen lebih senang dengan proses transaksi dengan sistem pembayaran otomatis (Repi et al., 2020). Disisi lain, nilai baik yang diperoleh dari pengalaman pribadi dan atau orang lain akan menyenangkan konsumen yang menguatkan konsumen untuk membeli kembali (Indriani, 2016).

Nilai yang dipersepsikan secara baik oleh konsumen mendorong pembelian ulang dan meningkatkan rasa puas yang akhirnya juga akan mendorong niat membeli kembali. Oleh karena itu tujuan penelitian ini untuk menganalisis pengaruh persepsi nilai terhadap minat beli ulang melalui kepuasan konsumen.

\section{Metodologi}

\subsection{Pengembangan Konsep}

\subsubsection{Minat Beli Ulang}

Studi mengenai minat beli ulang didasarkan pada Teori Ekspektasi-Konfirmasi (Oliver, 1981). Menurut teori ini persepsi mengarah pada kepuasan dan niat pembelian kembali (Thong et al., 2002). Minat beli merupakan bentuk kemungkinan konsumen berniat membeli suatu produk (Kotler \& Keller, 2016) sehingga minat beli ulang dapat dimaknai sebagai niat untuk membeli kembali. 
Minat beli dapat ditandai dengan: pertama, kecenderungan membeli kembali (transaksional); kedua, mereferensikan pembelian (referensional); ketiga, menadikan pilihan utama (preferensial); dan keempat, selalu mencari informasi (eksporatif) yang menyangkut hal-hal positif (Ferdinand, 2002a).

\subsubsection{Persepsi Nilai Pasca Pembelian dan Kepuasan Konsumen}

Persepsi nilai dapat diartikan sebagai perbandingan yang akan diterima dengan pengorbanan menurut pandangan konsumen. Persepsi nilai (perceived value) dapat juga merupakan perkiraan keberartian yang akan diterima konsumen saat membeli produk atau jasa (Tjiptono, 2019). Dengan demikian persepsi nilai pasca pembelian adalah nilai riil yang dirasakan konsumen setelah melakukan pembelian. Persepsi nilai dapat dilihat dari sudut pandang emosional, sosial, kualitas dan harga (Tjiptono, 2019). Persepsi nilai muncul dari informasi pihak lain atau pengalaman pribadi. Nilai yang diperseptikan baik oleh konsumen akan menumbuhkan kepuasan (Indriani, 2016). Kegiatn ekonomi dengan proses yang mudah, praktis, cepat, aman, nyaman mendorong kepuasan konsumen. Semakin tinggi ekpektasi konsumen akan sebuah produk membuat kepuasan konsumen makin tinggi (Semuel, 2006).

H1 : persepsi nilai berpengaruh terhadap kepuasan konsumen

\subsubsection{Kepuasan Konsumen dan Minat Beli Ulang}

Kepuasan merupakan perbandingan antara yang diharapkan dengan yang diterima (Tjiptono, 2019). Puas tidak puas dapat dilihat dimiliki atau tidaknya perasaan senang, suka, puas, atau gembira (Dutka, 1994). Konsumen yang senang pengalamannya dalam transaksi yang cepat, pembayarannya otomatis, variasi produk dan mudah akan melakukan pembelian berulang (Sudibyo et al., 2015). Pelanggan yang merasakan pengalaman menyenangkan akan bersedia mengeluarkan biaya untuk bertransaksi yang cenderung dilakukan berkelanjutan (Hellier, Geursen, Carr, \& Rickard, 2003). Semakin tinggi kegembiraan dengan proses pembelian yang cepat, otomatis, mudah dan mendapat produk bervariasi akan pembelian di tempat yang memuaskan tersebut sebagai pilah utama dalam pembelian sehingga pembeliannya berulang (Adji \& Semuel, 2014; Indriani, 2016; Martini, 2013).

H2 : kepuasan berpengaruh terhadap minat beli ulang

\subsubsection{Persepsi Nilai Pasca Pembelian, Kepuasan Konsumen dan Minat Beli Ulang}

Persepsi nilai mempengaruhi niat konsumen untuk melakukan pembelian ulang (Repi et al., 2020). Persepsi nilai tinggi terhadap keamanan, kenyamanan dan mendongkrak status dari sisi sosial mendorong tumbuhnya preferensi pada proses pembelian. Proses pembelian yang mudah, praktis dan cepat akan memunculkan kesediaan untuk merekomendasikan proses pembelian kepada pihak lain. Dengan kata lain semakin tinggi nilai yang dipersepsikan oleh 
konsumen akan membuat perilaku pembelian berulang semakin sering (Mariah \& Nurbaeti, 2019).

H3 : Persepsi nilai berpengaruh terhadap minat beli ulang melalui kepuasan

Persepsi nilai pasca pembelian terhadap kepuasan (Indriani, 2016; Semuel, 2006) dan kepuasan terhadap minat beli ulang telah diuraikan sebelumnya (Adji \& Semuel, 2014; Hellier et al., 2003; Indriani, 2016; Martini, 2013). Konsumen yang memiliki persepsi yang baik akan memiliki kepuasan lebih yang selanjutnya mendorong konsumen untuk melakukan pembelian berulang.

(Dutka, 1994)

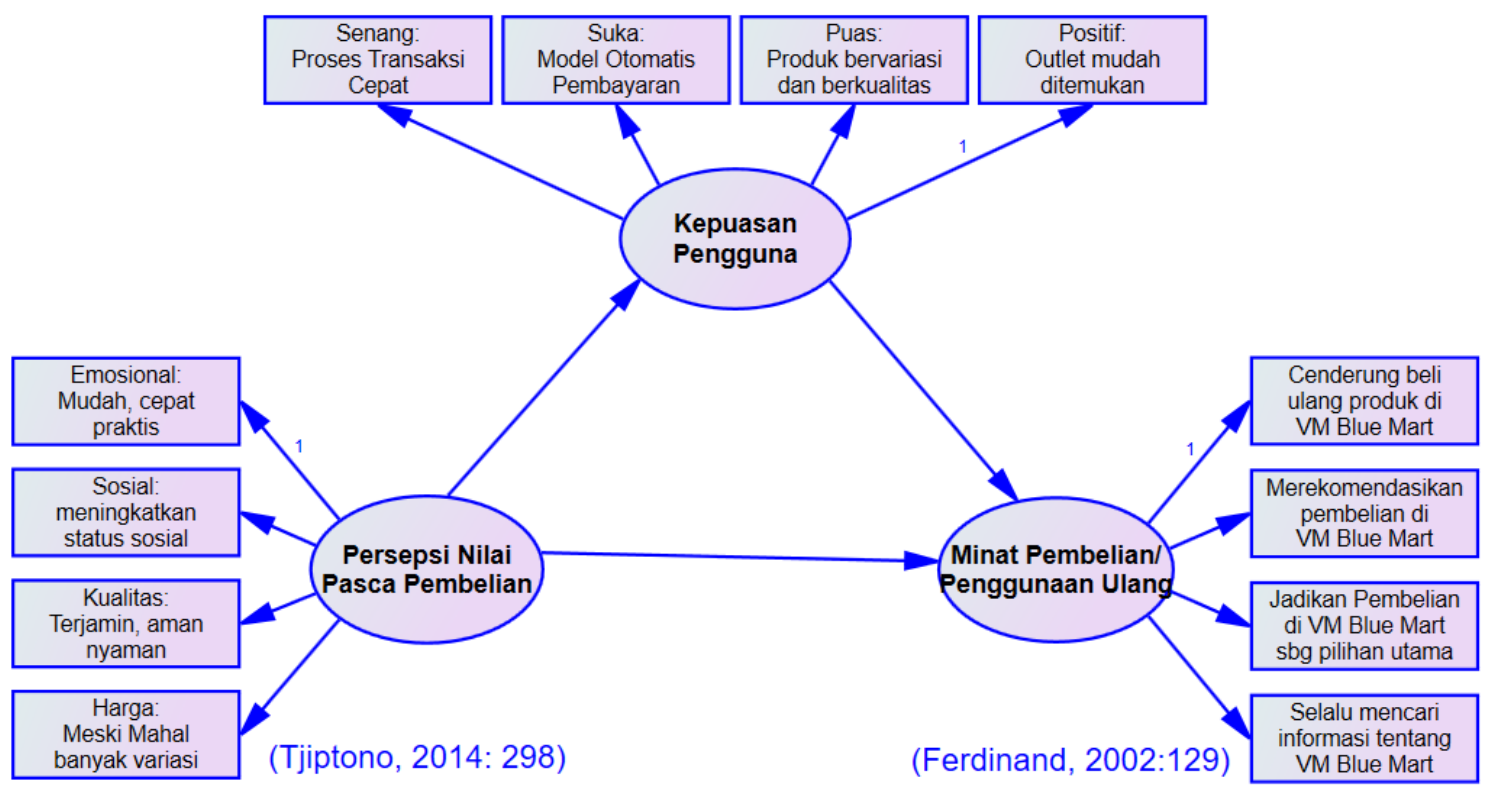

Sumber: Pengembangn model, 2020

Gambar 1. Desain Penelitian

\subsection{Pengumpulan Data}

Konsumen yang pernah belanja tau melakukan pembelian menggunakan mesin belanja otomatis Vending Machine Blue Mart.

Kuesioner digunakan sebagai instrumen pengambilan data. Pengukuran dengan skala bipolar dari 1 sampai dengan 5 yang menghasilkan data interval (Mulyanto \& Wulandari, 2010). Kuesioner dibuat dengan Google Form yang kemudian dibagikan ke berbagai kelompok WA group.

Pengambilan sampel purposive sampling digunakan dengan kriteria: Pertama, batas waktu pengisian adalah satu bulan yaitu selama November 2020; Kedua, memberikan respon dengan mengisi kuesioner; Ketiga, mengenal dan pernah bertransaksi menggunakan vending machine Blue Mart.

Sampai batas akhir ada 194 yang mengisi kuesioner. Setelah melalui screening tinggal 186 data yang digunakan sebagai sampel data karena data yang diisi delapan responden tidak lengkap. 


\subsection{Metode Analisis}

Analisis data menggunakan SEM (Structural Equation Modelling) dengan software AMOS Versi 23 (Ferdinand, 2002b). Beberapa tahapan dalam analisis yaitu: uji instrumen, uji kelayakan model, dan uji hipotesis.

Uji validitas instrumen menggunakan standar loading factor. Valid terpenuhi jika nilai loading factor lebih dari 0,5. Reliabilitas instrumen menggunakan composite reliability. Reliabilitas terpenuhi jika nila composite reliability lebih besar dari 0,7.

Kelayakan model diuji menggunakan beberapa kriteria seperti chi-square yang rendah, p-value kurang dari 0,05; Cmin/Df kurng dari 2. Kriteria berikutnya adalah TLI kurang dan CFI kurang dari 0,95. Kriteria lainnya yang paling utama adalah GFI dan AGFI kurang dari 0,90 serta RMSEA yang kurang dari 0,08.

Pengujian hipotesis dengan standard estimate dan p-value. Standard estimate menunjukkan besar dan arah pengaruh. P-value sebagai standar pengujian signifikansi dengan kriteria nilai p-value kurang dari 0,05.

\section{Hasil}

\subsection{Responden}

Responden penelitian berjumlah 186 yang dibedakan berdasar jenis kelamin, usia dan pendidikan. Karakteristik responden disajikan pada tabel 1.

Tabel 1. Data Responden

\begin{tabular}{lcc}
\hline \multicolumn{1}{r}{ Variabel } & Jumlah & Persen \\
\hline $\begin{array}{l}\text { Jenis Kelamin } \\
\text { - Perempuan }\end{array}$ & 135 & 73,78 \\
- Laki-laki & 51 & 27,87 \\
\hline Usia & & \\
- 15 Tahun-20 Tahun & 125 & 67,20 \\
- 21 Tahun-26 Tahun & 53 & 28,49 \\
- 26 Tahun-30 Tahun & 4 & 2,15 \\
- 31 Tahun-35 Tahun & 2 & 1,07 \\
- 35 Tahun-40 Tahun & 2 & 1,07 \\
\hline - Pendidikan & & \\
- SMA & 159 & 85,48 \\
- SMK & 17 & 9,13 \\
- Diploma & 8 & 4,30 \\
\hline
\end{tabular}

Sumber: Data hasil kuesioner yang diolah, 2020 


\subsection{Analisis}

Uji instrumen yaitu uji validitas reliabilitas sebagaimana tabel 2. Indikator pada masing-masing variabel telah valid (faktor loading $>0,5$ ). Selain itu seluruh variabel telah reliabel (composite reliability $>0,7$ ).

Tabel 2. Uji Instrumen

\begin{tabular}{|c|c|c|c|}
\hline Variabel/Indikator & $\begin{array}{l}\text { Loading } \\
\text { Factor }\end{array}$ & $\begin{array}{l}\text { Composite } \\
\text { Reliability }\end{array}$ & Hasil Uji \\
\hline Persepsi Nilai & & 0,744 & Reliabel \\
\hline - Proses mudah, praktis, cepat & 0.623 & & Valid \\
\hline - Transaksi meningkatkan status sosial & 0.666 & & Valid \\
\hline - Kualitas terjamin, aman, nyaman & 0.665 & & Valid \\
\hline - Harga lebih mahal tapi sesuai & 0.639 & & Valid \\
\hline Kepuasan & & 0,873 & Reliabel \\
\hline - Senang proses transaksi yang cepat & 0.842 & & Valid \\
\hline - Suka model pembayaran otomatis & 0.878 & & Valid \\
\hline - Puas dengan variasi produk dan kualitas & 0.856 & & Valid \\
\hline - Outlet mudah ditemukan & 0.581 & & \\
\hline Minat Beli Ulang & & 0,786 & Reliabel \\
\hline - Cenderung beli ulang & 0.737 & & Valid \\
\hline - Merekomendasikan & 0.723 & & Valid \\
\hline - Jadi pilihan pembelian utama & 0.536 & & Valid \\
\hline - Selalu mencari informasi & 0.761 & & Valid \\
\hline
\end{tabular}

Sumber: Hasil Pengolahan, 2020



Sumber: Data penelitian diolah, 2020

Gambar 2. Full Model Struktural 
Tabel 3. Goodness of fit Indices Structural Equation Model

\begin{tabular}{clccc}
\hline No. & Goodness & Cut off & Analisis & Evaluasi \\
\hline 1 & Chi-Square & Rendah & 80,789 & Poor \\
2 & P-Value & $\geq 0,05$ & 0,001 & Poor \\
3 & Cmin/DF & $\leq 2,00$ & 1,756 & Good \\
4 & GFI & $\geq 0,90$ & 0,936 & Good \\
5 & AGFI & $\geq 0,90$ & 0,891 & Marginal \\
6 & TLI & $\geq 0,95$ & 0,942 & Good \\
7 & CFI & $\geq 0,95$ & 0,960 & Good \\
8 & RMSEA & $\leq 0,08$ & 0,064 & Good \\
\hline
\end{tabular}

Sumber: Data Primer yang diolah, 2020

Tabel 3 sebagai pengukuran kebaikan model mendapatkan nilai Chi-Square dan p-value yang kurang baik serta AGFI yang marjinal. Sementara kriteria lainnya yaitu cmin/df, GFI, TLI, CFI dan RMSEA yang seluruhnya sudah baik. Dengan demikian maka secara umum model yang terbentuk dapat diterima sebagai model yang baik.

Tabel 4. Regression Weight $(\lambda \mathrm{i})$ Indikator

\begin{tabular}{lllrlll}
\hline & & Estimate & S.E. & C.R. & P \\
\hline ITU01 & $<---$ & ITU & 1.000 & & & \\
ITU02 & $<---$ & ITU & 1.047 & .121 & 8.685 & $* * *$ \\
ITU03 & $<---$ & ITU & .835 & .122 & 6.851 & $* * *$ \\
ITU04 & $<---$ & ITU & 1.280 & .140 & 9.146 & $* * *$ \\
PPV01 & $<---$ & PPPV & 1.000 & & & \\
PPV02 & $<---$ & PPPV & 1.097 & .146 & 7.494 & $* * *$ \\
PPV03 & $<---$ & PPPV & 1.218 & .183 & 6.649 & $* * *$ \\
PPV04 & $<---$ & PPPV & 1.102 & .172 & 6.397 & $* * *$ \\
SAT01 & $<---$ & SATIS & 1.380 & .186 & 7.408 & $* * *$ \\
SAT02 & $<---$ & SATIS & 1.404 & .198 & 7.099 & $* * *$ \\
SAT03 & $<---$ & SATIS & 1.033 & .131 & 7.891 & $* * *$ \\
SAT04 & $<---$ & SATIS & 1.000 & & & \\
\hline
\end{tabular}

Sumber: Data penelitian diolah, 2020

Tabel 4 menghasilkan nilai CR yang seluruhnya hampir seluruhnya lebih besar dari 1,96 dan $\mathrm{p}=* * *$ keculai pada alur ITU $\rightarrow$ ITU01, PPPV $\rightarrow$ PPV01 dan SATIS $\rightarrow$ SAT04 dengan nilai estimate $=1,000$. Pada kelompok CR dan P yang kosong menandakan bahwa indikator tersebut merupakan indikator utama dari setiap variabel. Indikator utama tidak memerlukan pengujian sehingga dengan data tersebut maka dapat disimpulkan bahwa tiap indikator pada model telah signifikan sebagai pembentuk indikator. 
Tabel 5. Estimasi Model Struktural

\begin{tabular}{lcccl}
\hline \multicolumn{1}{c}{ Alur } & $\begin{array}{c}\text { Std. } \\
\text { Estimates }\end{array}$ & C.R. & P & Kesimpulan \\
\hline Persepsi Nilai $\rightarrow$ Kepuasan & 0,561 & 4,644 & $* * *$ & Signifikan \\
Kepuasan $\rightarrow$ Minat beli ulang & 0,604 & 3,699 & $* * *$ & Signifikan \\
Persepsi Nilai $\rightarrow$ Minat beli ulang & 0,359 & 5,010 & $* * *$ & Signifikan \\
Persepsi Nilai $\rightarrow$ Kepuasan $\rightarrow$ & 0,201 & & & \\
Minat beli ulang & & & & \\
Total Persepsi Nilai $\rightarrow$ Minat beli & 0,805 & & & \\
\hline
\end{tabular}

Sumber: Data penelitian yang diolah, 2020

Tabel 5 sebagai memberikan informasi pengaruh dan signifikansi persepsi nilai terhadap minat beli ulang. Nilai $C R$ yang lebih besar dai 1,96 dan $p=* * *$ menunjukkan signifikansi pengaruh antar variabel. Persepsi nilai signifikan mempengaruhi kepuasan dengan arah positif. menunjukkan alur pengaruh antar variabel dalam model. Strategi bisnis berpengaruh terhadap komitmen organisasi dan komitmen organisasi berpengaruh terhadap kinerja manajerial. Strategi bisnis tidak secara langsung dapat mempengaruhi kinerja manajerial tetapi secara tidak langsung melalui komitmen organisasi berpengaruh dimana pengaruhnya secara total pengaruhnya semakin kuat.

\section{Pembahasan}

\subsection{Pengaruh Persepsi Nilai Terhadap Kepuasan}

Persepsi nilai berpengaruh searah dengan kepuasan konsumen dengan standar estimasi $=0,561$. Kemudahan, kepraktisan dan kecapatan pembelian menggunakan mesin penjualan otomatis (Vending Machine) Blue Mart memberikan rasa senang bagi konsumen. Sebaran outlet yang banyak dan mudah ditemukan sebagai gambaran nilai yang baik meningkatkan kepuasan konsumen Blue Mart.

Temuan penelitian sejalan dengan yang sebelumnya meskipun tinjauannya dari sisi bauran pemasaran (Sudibyo et al., 2015) tida secara tegas merujuk pada nilai. Penelitian ini sedikit berbeda dengan penelitian lainnya (Semuel, 2006) dimana bauran pemasaran dapat mempengaruhi kepuasan tetapi justru ekspektasi akan nilai yang diharapkan konsumen tidak berpengaruh terhadap kepuasan. Hasil penelitian ini sejalan dengan penelitian sebelumnya (Indriani, 2016) meskipun tidak secara tegas berbicara tentang nilai tetapi pada konteks pengalaman penggunaan yang menjadi ukuran nilai dapat mempengaruhi kepuasan.

Aplikasi Blue Mart, sebaiknya dapat melakukan improvement secara progresif yang berkaitan dengan persepsi nilai agar dapat meningkatkan minat beli. 


\subsection{Pengaruh Kepuasan Terhadap Minat beli ulang}

Konsumen yang puas adalah pelanggan yang mendapatkan apa yang diharapkan. Kepuasan berpengaruh searah dengan minat beli ulang konsumen Blue Mart dengan nilai standar estimasi $=0,604$. Konsumen yang puas cenderung melakukan pembelian kembali di tempat yang sama. Konsumen Blue Mart yang senang dengan proses transaksi yang cepat dan puas dengan model pembayaran otomatis di Vending Machine akan tergerak untuk merekomendasikan kepada pihak lain. Konsumen yang puas dengan variasi dan kualitas produk yang diterima pada saat melakukan pembelian di Blue Mart akan menjadikan Blue Mart sebagai pilihan utama dalam melakukan pembelian.

Adanya pengaruh kepuasan terhadap minat beli ulang sejalan dengan penelitian sebelumnya dimana pelanggan yang puas cenderung tertarik untuk membeli ditempat yang sama (Sudibyo et al., 2015). Penelitian ini juga sejalan dengan temuan peneliti lain (Adji \& Semuel, 2014) dimana kepuasan tidak sekedar mendorong minat tetapi sudah sampai pada loyalitas. Temuan penelitin ini dan sebelumnya yang telah diuraikan sebelumnya semakin menguatkan bahwa konsumen yang merasa puas dengan ditawarkan perusahaan, termasuk layanan pembelian otomatis di Blue Mart cenderung menarik minat konsumen untuk membeli kembali.

\subsection{Pengaruh Persepsi Nilai Terhadap Minat Beli Ulang}

Persepsi nilai yang baik berpengaruh searah dengan minat beli ulang konsumen Blue Mart dengan nilai standar estimasi $=0,359$. Nilai yang ditawarkan produsen yang mampu membangkitkan emosi dan derajat sosial konsumen membuat konsumen tertarik untuk melakukan pembelian ulang. Proses yang mudah, praktis dan cepat dalam proses pembelian di Blue Mart membuat konsumen cenderung melakukan pembelian ulang. Nilai sosial yang meningkat dengan penggunaan mesin otomatis dalam bertransaksi membuat konsumen tergerak untuk terus melakukan pencarian. Diperolehnya perasaan nyaman dan aman menjadikan Blue Mart sebagai pilihan utama dalam melakukan pembelian kembali.

Adanya pengaruh persepsi nilai terhadap minat beli ulang mengkonfirmasi kembali dan sejalan dengan penelitian sebelumnya (Mariah \& Nurbaeti, 2019; Wulandari \& Ekawati, 2015). Hasil penelitian ini juga sejalan dengan penelitan untuk produk tertentu yaitu kosmetik (Wiryantari \& Sukawati, 2016).

Penelitian ini juga menghasilkan temuan bahwa persepsi nilai mempengaruhi minat beli ulang secara tidak langsung yaitu melalui kepuasan. Kepuasan sebagai intervening minat beli sejalan dengan penelitian sebelumnya (Sudibyo et al., 2015) meskipun faktor yang digunakan adalah persepsi bauran pemasaran. Meskipun dalam penelitian lain (Semuel, 2006) kepuasan dapat memediasi baruan pemasaran terhadap minat beli ulang tetapi tidak dapat sebagai intervening untuk ekspektasi. Adanya pengaruh tidak langsung temuan penelitian ini, dapat diartikan bahwa persepsi nilai yang ada di benak konsumen 
akan mempengaruhi minat beli ulang ketika sebelumnya mampu membangkitkan kepuasan konsumen.

\section{Kesimpulan}

Persepsi nilai berpengaruh terhadap minat beli ulang dengan arah positif. Persepsi nilai mempengaruh secara langsung minat beli ulang dipihak lain persepsi nilai meningkatkan kepuasan dan dengan kepuasan tersebut konsumen akan berminat untuk melakukan pembelian kembali.

Blue mart hendaknya menjaga kualitas memastikan proses terjamin aman dan nyaman, memberi kesan bahwa transaksi melalui vending machine meningkatkan status sosial. Perusahaan vending machine aplikasi Blue mart hendaknya berupaya memberikan kepuasan kepada konsumennya. Hal ini dapat dilakukan dengan memenuhi harapan dalam proses transaksi yang cepat, pembayaran otomatis dengan menu yang mudah, penyediaan produk bervariasi dan berkualitas, dan menempatkan vending machine di tempat strategis.

\section{Daftar Pustaka}

Adji, J., \& Semuel, H. (2014). Pengaruh Satisfaction dan Trust Terhadap Minat Beli Konsumen (Purchase Intention) di Starbucks the Square Surabaya. Jurnal Manajemen Pemasaran Petra, 2(1), 1-10.

Dutka, A. (1994). AMA Hand Book for Customer Satisfaction. Lincolnwood, Illinois.: NTC Bussiness Book.

Ferdinand, A. (2002a). Pengembangan Minat Beli Merek Ekstensi. Semarang.: Badan Penerbit Universitas Diponegoro.

Ferdinand, A. (2002b). Structural Equation Modelling Dalam Peneltian Manajemen. Edisi 2. Semarang: BP Undip.

Hellier, P. K., Geursen, G. M., Carr, R. A., \& Rickard, J. A. (2003). Customer repurchase intention. A general structural equation model. European. Journal of Marketing, 37(11/12).

Indriani, F. (2016). Experiential Marketing sebagai Suatu Strategi dalam Menciptakan Customer Satisfaction dan Repeat Buying untuk Meningkatkan Kinerja Pemasaran. Jurnal Studi Manajemen E Organisasi, 3(1), 37-54.

Kotler, P., \& Keller, K. L. (2016). Manajemen Pemasaran. Jakarta: Erlangga.

Kurniawan, I., santoso, S. B., \& Dwiyanto, B. M. (2007). Analisis Faktor-Faktor yang Mempengaruhi Minat Beli Ulang Produk serta Dampaknya Terhadap Loyalitas Pelanggan (Studi Kasus Pada Produk Sakatonik Liver di Kota Semarang). Jurnal Studi Manajemen E Organisasi, 4(2), 27-42.

Mariah, M., \& Nurbaeti, D. (2019). Pengaruh persepsi online store dan offline store pada persepsi nilai dan dampaknya terhadap minat beli pada produk fashion. Jurnal Manajemen Strategi dan Aplikasi Bisnis, 2(2), 215-222. 
Martini, L. K. B. (2013). Relationship Marketing, Customer Satisfaction, Customer Commitment dan Customer Loyalty (Studi pada Sebuah Bank Nasional di Denpasar). Buletin Studi Ekonomi, 18(3), 9-25.

Mulyanto, H., Rasipan, \& Andriani, M. (2018). Reputasi Dalam Mendorong Kepercayaan dan Minat Konsumen Produk Makanan UMKM di Cileungsi. Jurnal Manajemen Kewirausahaan, 15(2), 10 . doi: http://dx.doi.org/10.33370/jmk.v15i2.270

Mulyanto, H., \& Wulandari, A. (2010). Penelitian: Metode \& Analisis: CV Agung Semarang; ISBN No. 978-979-704-990-4.

Oliver, R. L. (1981). Measurement and Evaluation of Satisfaction Process in Retail Settings. Journal of Retailing, 57, 25-48.

Pradini, A. L. W. (2012). Analisis Pengaruh Kualitas Layanan dan Brand Image Terhadap Minat Beli Ulang pada Restoran Kentucky Fried Chicken (KFC) Salatiga. (Diploma Thesis), Universitas Kristen Satya Wacana, Salatiga. Retrieved from http://repository.uksw.edu/handle/123456789/2608 (271)

Putra, A. B., Lapian, J., \& Lumanauw, B. (2014). Bauran Pemasaran Pengaruhnya Terhadap Minat Membeli Kembali Voucher Isi Ulang Telkomsel. Jurnal EMBA, 2(3), 428-437.

Repi, O. W., Lumanaw, B., \& Wenas, R. S. (2020). Pengaruh Bauran Promosi, Kesadaran Merek dan Persepsi Nilai Terhadap Minat Beli di Bukalapak pada Mahasiswa Fakultas Ekonomi dan Bisnis Universitas Sam Ratulangi Manado. Jurnal EMBA, 8(4), 110-119.

Semuel, H. (2006). Ekspektasi Pelanggan dan Aplikasi Bauran Pemasaran Terhadap Loyalitas Toko Modern dengan Kepuasan Pelanggan sebagai Intervening (Studi Kasus pada Hypermarket Carrefour di Surabaya). Jurnal Manajmen Pemasaran, 1(2), 53-64.

Sudibyo, A. N., Margo, C., \& Andreani, F. (2015). Analisa Pengaruh Bauran Pemasaran Terhadap Minat Beli Ulang dengan Kepuasan Konsumen sebagai Variabel Perantara di Domicile Kitchen and Lounge. Jurnal Hospitality dan Manajemen Jasa, 2, 460-474.

Thong, J., Hong, W., \& Tam, K. (2002). Understanding user acceptance of digital libraries: What are the roles of interface characteristics, organizational context, and individual differences. International Journal of HumanComputer Studies, 57(3), 215-242.

Tjiptono, F. (2019). Strategi Pemasaran. Yogyakarta: Andi.

Wiryantari, A. A. I. C., \& Sukawati, T. G. R. (2016). Peran Persepsi Nilai dalam Memediasi Pengaruh Kredibilitas Celebrity Endorser pada Niat Beli Produk Kosmetik Wardah. E-Jurnal Manajemen Unud, 5(11), 7100-7127.

Wulandari, N. L. P. S., \& Ekawati, N. W. (2015). Peran Kepercayaan dalam Memediasi Persepsi Nilai Terhadap Niat Beli Produk Ramah Lingkungan. E-Jurnal Manajemen Unud, 4(7), 2095-2109. 